\title{
PENGARUH KOMPENSASI DAN MOTIVASI TERHADAP KINERJA KARYAWAN PADA HOTEL ASTON KUPANG \& COVENTION CENTER
}

\author{
Dra. Rulli Saragi,M.Hum \\ Jurusan Pariwisata, Politeknik Negeri Kupang \\ Jl. Adisucipto Kampus Penfui-Kupang NTT \\ E-mail: Rullysaragi93@gmail.com
}

\begin{abstract}
Abstrak
The title of this research is "The influence of compensation and motivation on employee performance at on Hotel Aston Kupang \& Covention Center". The main problem formulation in this research how competation, motivation effect on employee performance at on Hotel Aston Kupang \& Covention Center. The purpose of this research is to answer the problem to know how to compensate and motivation effect on employee performance at On Hotel Aston Kupang \& Covention Center and to find out whether compencation, motivation partiali and simultaneously effect of employee performes at Hotel Aston Kupang \& Covention Center.

The result show that show that competation, motivation effect and employee performance on Hotel Aston Kupang \& Covention Center on goodness category and there compentation, motivation, and employee performance effect as partiali and simultaneously.
\end{abstract}

Key Words : Competation, Motivation, and Employee Performance

\section{PENDAHULUAN}

Kinerja diartikan sebagai hasil usaha seseorang yang dicapai dengan kemampuan dan perbuatan dalam situasi tertentu. Menurut Simamora (2004:339), kinerja karyawan adalah tingkat para karyawan mencapai persyaratan perusahaan. Dari pendapat diatas dapat dijelaskan bahwa yang dimaksud dengan kinerja adalah hasil yang dicapai seseorang menurut ukuran yang berlaku untuk pekerjaan yang bersangkutan.

Artinya perilaku seseorang memberikan hasil pekerjaan yang sesuai dengan standar atau kriteria yang dilakukan organanisasi, maka kinerjanya yang tergolong baik, dan jika sebaliknya berarti kinerjanya buruk. Atau dengan kata lain, penetapan standar diperlukan untuk apakah besarnya penyimpangan dengan cara membandingkan dengan hasil pekerjaan secara aktual dengan hasil yang diharapkan.

Dalam pencapaian tujuan perusahaan, diharapkan kinerja karyawan Hotek Hotel Aston Kupang \& Covention Center dapat meningkat. Akan tetapi pada kenyataannya kinerja karyawan Hotel Aston Kupang \& Covention Center mengalami pasang surut. Masalah penurunan kinerja karyawan terjadi di Hotel Hotel Aston Kupang \& Covention Center diakibatkan lemahnya pemberian kompensasi dan dorongan motivasi kepada karyawan.
Kompensasi yang diterima karyawan di Hotel Aston Kupang \& Covention Center berbeda-beda tergantung pada jabatan dan lamanya bekerja. Gaji yang diberikan karyawan sudah UMR (Upah minimum regional) bagi karyawan dengan jam serta beban kerja yang mereka terima itu tidak sepadan. Karyawan akan merasa pekerjaannya tidak dihargai oleh atasan. Kurangnya perhatian atas pemberian kompensasi oleh atasan juga membuat kinerja karyawan Hotel Hotel Aston Kupang \& Covention Center menjadi menurun.

\section{Rumusan Masalah}

Berdasarkan Rumusan masalah diatas maka tujuan dari penelitian adalah :

a. Untuk mengetahui pengaruh kompensasi secara parsial terhadap kinerja karyawan Hotel Aston Kupang \& Covention Center

b. Untuk mengetahui pengaruh motivasi secara parsial terhadap kinerja karyawan Hotel Aston Kupang \& Covention Center

c. Untuk mengetahui pengaruh kompensasi dan motivasi secara simultan terhadap kinerja secara simultan.

Tujuan Penelitian

Berdasarkan Rumusan masalah diatas maka tujuan dari penelitian adalah : 
a. Untuk mengetahui pengaruh kompensasi secara parsial terhadap kinerja karyawan Hotel Aston Kupang \& Covention Center.

b. Untuk mengetahui pengaruh motivasi secara parsial terhadap kinerja karyawan Hotel Aston Kupang \& Covention Center.

c. Untuk mengetahui pengaruh kompensasi dan motivasi secara simultan terhadap kinerja secara simultan.

\section{TINJAUAN PUSTAKA}

\section{KOMPENSASI}

Kompensasi merupakan salah satu faktor dan menjadi perhatian banyak organisasi dalam mempertahankan dan menarik sumber daya manusia yang berkualiatas. Berbagai organisasi berkompetisi untuk memperoleh sumber daya yang berkualitas, karena kualiatas hasil pekerjaan ditentukan oleh kompetensi yang dimiliki sumber daya manusianya. Alasan membuat banyak organisasi mengeluarkan sejumlah dana yang relatif besar untuk mengembangkan sumber daya manusianya agar memiliki kompensasi sesuai kebutuhan, Bangun ( Kadarisman, 2012 : 43 ).

Menurut Wibowo (2011: 348), kompensasi merupakan kontraprestasi terhadap penggunaan tenaga atau jasa yang telah diberikan oleh tenaga kerja. Wibowo juga mengatakan kompensasi merupakan jumlah paket yang ditawarkan organisasi kepada pekerja sebagai imbalan atau penggunaan kerjanya. Kadarisman (2012: 1), mengemukakan kompensasi adalah apa yang seseorang karyawan/pegawi/pekerja terima sebagai balasan dari pekerjaan yang diberikannya. Kompensasi yang diberikan organisasi ada yang berbentuk uang, namun ada yang tidak berbentuk uang. Kompensasi yang berwujud upah pada umumnya berbentuk uang, sehingga kemungkinan nilai rilnya turun naik.

Berdasarkan pendapat para ahli diatas, maka dapat diambil kesimpulan bahwa kompensasi merupakan interaksi antar karyawan dengan organisasi, yang berupa timbal balik dari jasa atau tenaga yang dikeluarkan kayawan dan perhargaan dari organisasi dalam bentuk upah atau fasilitas lainnya.

\section{MOTIVASI}

Motivasi merupakan keinginan seseorang melakukan sesuatu akibat dorongan dari diri sendiri maupun dari luar diri pegawai. Selain itu motivasi dapat pula diartikan sebagai dorongan karyawan untuk melakukan tindakan karena mereka ingin melakukannya. Menurut Mangkunegara (2009: 93), berpendapat bahwa motivasi adalah kondisi yang menggerakan pegawai agar mampu mencapai tujuan dari motifnya. Menurut Wibowo (2010: 379) motivasi merupakan dorongan terhadap serangkaian proses perilaku manusia pada pencapaian tujuan. Sedangkan elemen yang terkandung dalam motivasi meliputi unsur membangkitkan, mengarahkan, menjaga menunjukan intensitas bersifat terus menerus dan adanya tujuan.

Berdasarkan berbagai pendapat diatas, dapat dikatakan bahwa motivasi timbul dalam diri karyawan atau melalui ransangan dari luar diri karyawan tersebut. Dalam sebuah perusahaan, Pemimpin dalam perusahaan dituntut memainkan peran yang lebih dalam memberikan ransangan dan dorongan agar pegawainya semakin termotivasi dalam menghasilkan output yang memuaskan dan terus berusaha meningkatkan lagi hasil kerjanya.

\section{KINERJA}

Kinerja karyawan adalah hasil kerja yang dicapai seseorang atau kelompok orang sesuai dengan wewenang atau tanggung jawab masing-masing karyawan selama periode tertentu (Pabunda Tika, 2006: 212 ), sebuah perusahaan perlu melakukan penilaian kinerja karyawannya. Penilaian kinerja dinilai memainkan peranan yang sangat penting dalam peningkatan motivasi di tempat kerja. Penilaian hendaknya memberikan suatu gambaran akurat serta motivasi kerja.

Kusriyanto (dalam Mangkunegara, 2005: 9), mendefenisikan kinerja sebagai perbandingan hasil kerja yang capai dengan peran serta tenaga kerja persatuan waktu (lazimnya per jam ) Selanjutnya menurut Gomes (dalam Mangkunegara, 2005: 9), mengatakan bahwa defenisi kerja karyawan sebagai “ Ungkapan seperti output, efisiensi serta efektivitas sering dihubungkan dengan produktifitas".

\section{Konsep Penelitian}

Defenisi operasional, indikator empirik dan skala pengukuran konsep dalam penelitian ini dapat dijelasakan pada tabel berikut ini: 
Tabel 2

Variabel,Definisi Operasional,Indikator dan Skala Pengukuran

\begin{tabular}{|c|c|c|c|}
\hline Variabel & Indikator & Definisi Operasional & Skala \\
\hline $\begin{array}{l}\text { Kompensasi } \\
(x 1) \\
\text { Hasibuan } \\
(2009: 123)\end{array}$ & $\begin{array}{ll}1 & \text { Puas terhadap gaji } \\
2 & \text { Puas terhadap } \\
\text { fasilitas }\end{array}$ & $\begin{array}{llr}1 & \begin{array}{l}\text { Hak karyawan } \\
\text { kompensasinya }\end{array} & \begin{array}{r}\text { atas } \\
\text { terhadap }\end{array} \\
& \begin{array}{l}\text { perusahaan. } \\
\text { Kompensasi }\end{array} & \text { sebagai } \\
\text { penunjang } & \text { kelancaran } \\
\text { untuk bekerja dan } & \text { memotivasi } \\
& \text { karyawan. } & \end{array}$ & Interval \\
\hline $\begin{array}{l}\text { Motivasi } \\
(x 2) \\
\text { Siagian } \\
(2004: 138)\end{array}$ & $\begin{array}{l}1 \text { Usaha Karyawan } \\
2 \text { Kebutuhan rasa } \\
\begin{array}{l}\text { aman } \\
\text { keselamatan }\end{array}\end{array}$ & $\begin{array}{ll}1 \text { Usaha keras yang di lakukan } \\
\text { karyawan dalam bekerja. } \\
2 \text { keamanan dan keselamatan kerja } \\
\text { yang diantaranya } \\
\text { seperti adanya jaminan sosial } \\
\text { tenaga kerja. }\end{array}$ & Interval \\
\hline $\begin{array}{l}\text { Kinerja } \\
\text { (Y) } \\
\text { Dharma } \\
(2003: 355)\end{array}$ & $\begin{array}{l}\text { 1.Kualitas } \\
\text { 2.Kuantitas }\end{array}$ & \begin{tabular}{|lll}
1 & $\begin{array}{l}\text { Seberapa baik karyawan } \\
\text { mengerjakan apa yang harus } \\
\text { dikerjakan }\end{array}$ \\
2 & $\begin{array}{l}\text { Seberapa lama seorang karyawan } \\
\text { bekerja dalam satu harinya }\end{array}$
\end{tabular} & \\
\hline
\end{tabular}

\section{Kerangka Berpikir}

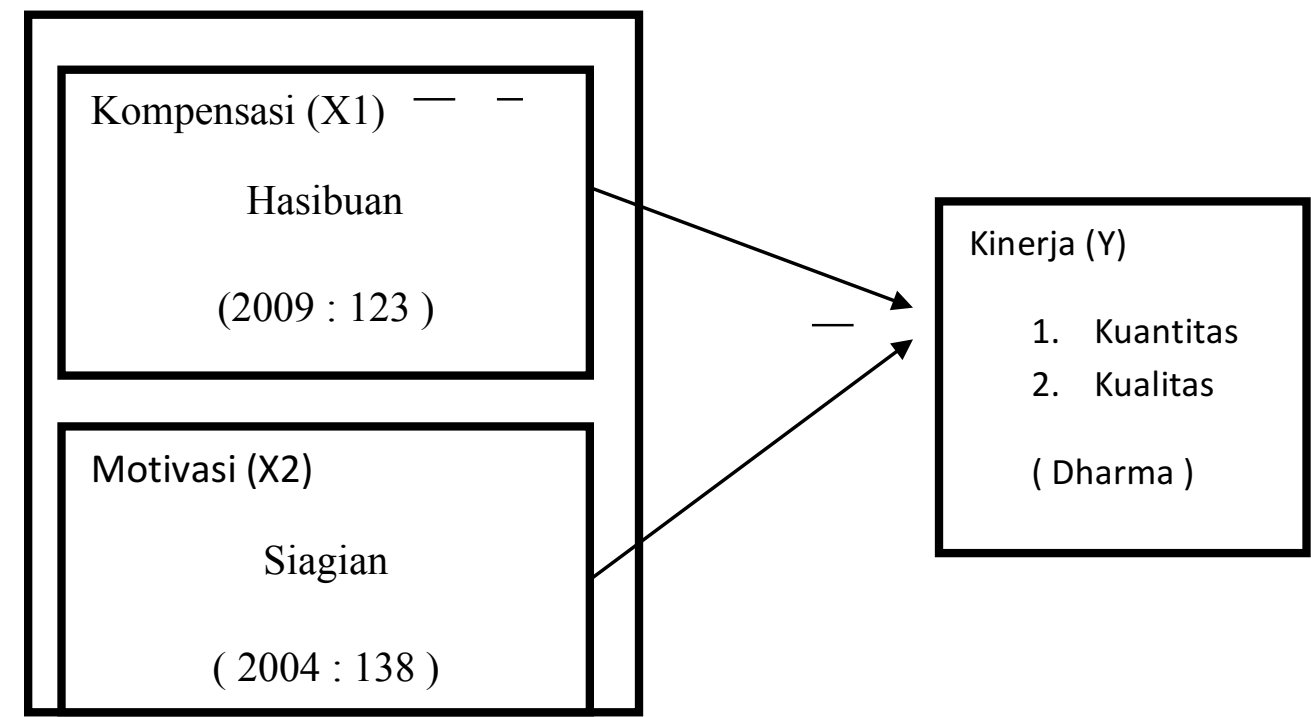

\section{METODE PENELITIAN}

Jenis penelitian ini adalah penelitian survey yaitu penelitian yang dilakukan pada populasi besar ataupun kecil tetapi data yang dipelajari adalah data yang diambil dari populasi tersebut (Sugiyono $2012: 7$ )
Jenis dan Sumber Data

1. Jenis Data

a. Data Kuantitatif

Data kualitatif yaitu data yang diperoleh dari Hotel On The Rock Kupang, dalam bentuk informasi atau keterangan-keterangan yang bukan dalam bentuk angka-angka tetapi dalam bentuk lisan dan tertulis. Data kualitatif ini seperti sejarah berdirinya sebuah perusahaan, 
struktur organisasi, Dan uraian tugas masingmasing bagian dalam perusahaan.

\section{b. Data Kualitatif}

Data Kuantitatif yaitu penulis menganalisa data dengan menggunakan skala likert (sugiyono 2012: 107) Dengan skala pengukuran dan perhitungan sebagai berikut : 5 = Untuk jawaban sangat setuju

4 = Untuk jawaban setuju

3 = Untuk jawaban kurang setuju

2 = Untuk jawaban tidak setuju

1= Untuk jawaban sangat tidak setuju

\section{Sumber Data}

1) Data Primer

Data Primer adalah data yang diperoleh langsung dari responden lewat teknik pengumpulan data.

1. Observation (pengamatan langsung)

Yaitu teknik pengumpulan data dengan cara mengamati secara langsung terhadap objek penelitian, yaitu pada karyawan hotel. Instrumen yang digunakan dalam observation dibuat dalam bentuk checklist.

\section{Questinare/Angket}

Yaitu teknik pengumpulan data yang dilakukan dengan cara memberi pertanyaan pertanyaan secara tertulis yang harus diisi oleh sampel, dengan cara menyebarkan daftar pertanyaan pada responden dengan harapan mereka akan memberikan respon atas daftar pertanyaan. Instrumen yang digunakan dalam survey dibuat dalam bentuk kuesioner (angket).

3. Interview (wawancara)

Yaitu teknik pengumpulan data yang dilakukan dengan cara member pertanyaan pertayaan secara langsung yang ditanyakan oleh peneliti kepada pihak manajemen hotel serta karyawan hotel. Instrument yang digunakan dalam interview dibuat dalam bentuk pedoman wawancara.

\section{POPULASI DAN SAMPEL}

\section{Populasi}

Populasi adalah wilayah generalisasi yang terdiri dari atas obyek atau subyek yang mempunyai kualitas dan karakteristik tertentu yang ditetapkan oleh peneliti untuk dipelajari dan kemudian ditarik kesimpulannya, Sugiono (2012: 62 ). Yang menjadi populasi dalam penelitian iniadalah karyawan Hotel Aston Kupang \& Covention Center Kupang sebanyak 55 (lima puluh lima ) orang.

\section{Sampel}

Sampel adalah bagian dari jumlah karakteristik yang dimiliki oleh populasi tersebut, Sugiono (2012: 60). Dalam penelitian ini penulis menentukan sampel dengan menggunakan Sampling Jenuh (sensus). Sampling jenuh adalah teknik penentuan sampling bila semua anggota populasi digunakan sebagai sampel. Hal ini sering dilakukan bila jumlah populasi relatif kecil, kurang dari 30 orang, atau penelitian yang ingin membuat generalisasi dengan kesalahan yang sangat kecil .

\section{TEKNIK PENGUMPULAN DAN ANALISIS DATA}

\section{Alat Pengumpulan Data}

1) Observasi

Observasi yaitu teknik atau metode menganalisa dan mengadakan pencatatan secara sistematis dan pengamatan secara langsung mengenai tingkah laku atau aktifitas karyawan Hotel Aston Kupang \& Covention Center.

2) Wawancara

Wawancara yaitu merupakan proses tanya jawab secara langsung antara dua orang atau lebih, dan berlangsung antara narasumber dan pewawancara. Tujuan dari wawancara adalah untuk mendapatkan informasi-informasi dari karyawan perusahaan dengan cara peneliti memberikan pertanyaan untuk dijawab oleh orang yang diwawancarai Wawancara dilakukan berdasarkan daftar pertanyaan atau pedoman yang telah disiapkan secara baik.

\section{3) Kuesione.}

Kousioner adalah teknik pengumpulan data yang dilakukan dengan cara memberi seperangkat pertanyaan atau pernyataan tertulis kepada responden untuk dijawab.

4) Study kepustakan.

Study kepustakan yaitu peneliti mengambil reverensi literatu-literatur atau kepustakaan yang berhubungan dengan materi penelitian.

\section{Teknik Analisis Data Uji Instrumen}

\section{Uji Validitas}

Uji valibilitas digunakan untuk mengetahui kelayakan butir-butir dalam suatu daftar pertanyaan dalam mendefenisikan suatu variabel (Ghozali,2005: 108). Pengujian validitas dilakukan dengan menggunakan alat bantu program statistik dengan criteria sebagai berikut:

Jika $r$ hitung positif dan $r$ hitung $>r$ table maka butir pertanyaan tersebut valid.

Jika $r$ hitung negatif dan $r$ hitung $<r$ table maka butir pertanyaan tersebut tidak valid.

\section{Uji Reliabilitas}

Reabilitas ( keandalan ) merupakan ukuran sesuatu kestabilan dan konsintensi responden dalam menjawab hal yang berkaitan 
dengan hal-hal pertanyaan yang merupakan dimensi suatu variabel dan disusun dalam suatu bentuk kuesioner.

Realibilitas suatu konstruk variabel dikatakan baik jika memiliki Cronbach's Alpha > 0,60 (Ghozali,2005:109). Tabel.jika t hitung $\geq \mathrm{t}$ tabel maka hipotesis diterima dan sebaliknya. Bisa juga membandingkan nilai alpha(0.05) $5 \%$ dengan nilai signifikan (nilai P-value ). $\geq 0,05$ maka hipotesis ditolak.

\section{Tahap Analisis}

Tahap ini merupakan bentuk analisis dengan memperhatikan hasil-hasil analisi dan tabulasi data pada tahap sebelumnya. Pada tahap ini penulis akan berupaya mendapatkan persamaan dalam regresi linear berganda untuk memprediksi nilai variabel kompensasi dan variabel motivasi berdasarkan nilai variabel kinerja. Data yang nantinya terkumpul akan dianalisis dengan analisis regresi linear berganda dengan rumus (Sugiyono 2012 : 218 ).

Data yang nantinya telah terkumpul kan dianalisis dengan analsis regresi linear berganda dengan rumus (Sugiyono 2012 : 218) $Y=a+b 1 X 1+b 2 X 2$

\begin{tabular}{lll}
\multicolumn{2}{c|}{ Dimana } & \\
$\mathrm{Y}$ & $=$ & Kinerja \\
$\mathrm{A}$ & $=$ & Konstanta \\
$\mathrm{B} 1 \mathrm{~b} 2$ & $=$ & Koefisien regresi \\
$\mathrm{X} 1=$ & Kompensasi \\
$\mathrm{X} 2=$ & Motivasi
\end{tabular}

\section{HASIL DAN PEMBAHASAN}

\section{Kompensasi}

Variabel Kompensasi adalah sebesar $83,16 \%$ dengan perincian pada indikator puas terhadap gaji $80,33 \%$. Pada item pertanyaan produk yang ditawarkan Gaji yang diberikan kepada karyawan sudah memadai responden yang menjawab sangat setuju sebanyak 7 orang $(23,33 \%)$, responden yang menjawab setuju sebanyak 11 orang $(36,66 \%)$, responden yang menjawab kurang setuju sebanyak 10 orang $(33,33 \%)$, dan responden yang menjawab tidak setuju 2 orang $(6,66 \%)$ dan sangat tidak setuju tidak ada $(0,00 \%)$.

Pada item pertanyaan Gaji yang diberikan sudah sesuai dengan kinerja karyawan responden yang menjawab sangat setuju sebanyak 7 orang $(23,33 \%)$, responden yang menjawab setuju sebanyak 16 orang $(36,66 \%)$, responden yang menjawab kurang setuju sebanyak 7 orang $(6,66 \%)$, responden yang menjawab tidak setuju dan sangat tidak setuju tidak ada atau $0,00 \%$.

Pada item pertanyaan Gaji yang diberikan sudah dapat memenuhi kebutuhan karyawan responden yang menjawab sangat setuju sebanyak 11 orang $(36,66 \%)$, responden yang menjawab setuju sebanyak 13 orang $(43,33 \%)$, responden yang menjawab kurang setuju sebanyak 6 orang $(20,0 \%)$, responden yang menjawab tidak setuju dan sangat tidak setuju tidak ada atau $0,00 \%$

Pada item pertanyaan Gaji yang diberikan sudah sesuai dengan peraturan yang berlaku responden yang menjawab sangat setuju sebanyak 11 orang $(36,66 \%)$, responden yang menjawab setuju sebanyak 12 orang $(40,0 \%)$, responden yang menjawab kurang setuju sebanyak 7 orang $(23,33 \%)$, responden yang menjawab tidak setuju dan sangat tidak setuju adalah $0,00 \%$

Pada item pertanyaan Fasilitas yang diberikan sudah memadai responden yang menjawab sangat setuju sebanyak 10 orang $(33,33 \%)$, responden yang menjawab setuju sebanyak 15 orang $(50,0 \%)$, kurang setuju sebanyak 5 orang $(16,66 \%)$ dan responden yang menjawab tidak setuju dan sangat tidak setuju adalah $0,00 \%$.

Pada item pertanyaan Fasilitas yang diberikan sudah sesuai dengan kinerja karyawan responden yang menjawab sangat setuju sebanyak 11 orang $(36,66 \%)$, responden yang menjawab setuju sebanyak 11 orang $(36,66)$, responden yang menjawab kurang setuju sebanyak 7 orang $(23,33)$, responden yang menjawab tidak setuju sebanyak 1 orang $(3,33)$, dan responden yang menjawab sangat tidak setuju adalah $0,00 \%$.

Pada variabel Kompensasi item pertanyaan Gaji yang diberikan sudah dapat memenuhi kebutuhan karyawan dan Fasilitas yang diberikan sudah memadai mendapatkan nilai tertinggi sebesar 83,16, hal ini menandakan bahwa karyawan pada Hotel Aston Kupang \& Covention Center sudah terpuaskan dengan fasilitas yang di berikan untuk dapat meningkatkan kinerja karyawan Hotel Aston Kupang \& Covention Center. Sedangkan item pertanyaan kompensasi Gaji yang diberikan sudah sesuai dengan kinerja karyawan mendapatkan nilai terendah sebesar 75,33 . Hal ini menandakan bahwa manajement Hotel Aston Kupang \& Covention Center harus lebih memberikan bonus pada karyawan hotel agar dapat meningkat motivasi kerja pada karyawan hotel. 
Capaian Indikator Variabel Kompensasi

\begin{tabular}{|c|c|c|c|c|c|c|c|c|c|c|c|c|c|}
\hline \multirow{3}{*}{ Indikator } & \multicolumn{9}{|c|}{ Jawaban Pertanyaan } & \multicolumn{2}{|c|}{ Total } & \multirow{2}{*}{\multicolumn{2}{|c|}{$\begin{array}{l}\text { Capaian } \\
\text { Indikator }\end{array}$}} \\
\hline & \multicolumn{2}{|r|}{5} & \multicolumn{2}{|c|}{4} & 3 & \multicolumn{2}{|l|}{2} & \multicolumn{2}{|c|}{1} & \multirow[b]{2}{*}{$\%$} & \multirow[b]{2}{*}{$\mathbf{F}$} & & \\
\hline & $\bar{F}$ & $\%$ & $F$ & $\%$ & $F$ & $\%$ & $\bar{F}$ & $\%$ & $F$ & & & $\%$ & $\%$ \\
\hline Puas Terhadap Gaji & & & & & & & & & & & & & 80,33 \\
\hline $\begin{array}{l}\text { 1. Gaji yang diberikan } \\
\text { kepada karyawan } \\
\text { sudah memadai }\end{array}$ & 7 & $\begin{array}{c}23,3 \\
3\end{array}$ & 11 & $\begin{array}{c}36,6 \\
6\end{array}$ & $\begin{array}{l}1 \\
0\end{array}$ & $\begin{array}{c}33,3 \\
3\end{array}$ & 2 & $\begin{array}{c}6,6 \\
6\end{array}$ & 0 & $\begin{array}{c}0,0 \\
0\end{array}$ & $\begin{array}{l}3 \\
0\end{array}$ & 100 & 75,33 \\
\hline $\begin{array}{l}\text { 2. Gaji yang diberikan } \\
\text { sudah sesuai dengan } \\
\text { kinerja karyawan }\end{array}$ & 7 & $\begin{array}{c}23,3 \\
3\end{array}$ & 16 & $\begin{array}{c}36,6 \\
6\end{array}$ & 7 & 6,66 & 0 & $\begin{array}{l}0,0 \\
0\end{array}$ & 0 & $\begin{array}{c}0,0 \\
0\end{array}$ & $\begin{array}{l}3 \\
0\end{array}$ & 100 & 80,00 \\
\hline $\begin{array}{l}\text { 3. Gaji yang diberikan } \\
\text { sudah dapat } \\
\text { memenuhi } \\
\text { kebutuhan karyawan }\end{array}$ & $\begin{array}{l}1 \\
1\end{array}$ & $\begin{array}{c}36,6 \\
6\end{array}$ & 13 & $\begin{array}{c}43,3 \\
3\end{array}$ & 6 & 20,0 & 0 & $\begin{array}{c}0,0 \\
0\end{array}$ & 0 & $\begin{array}{c}0,0 \\
0\end{array}$ & $\begin{array}{l}3 \\
0\end{array}$ & 100 & 83,33 \\
\hline $\begin{array}{l}\text { 4. Gaji yang diberikan } \\
\text { sudah sesuai dengan } \\
\text { peraturan yang } \\
\text { berlaku }\end{array}$ & $\begin{array}{l}1 \\
1\end{array}$ & $\begin{array}{c}36,6 \\
6\end{array}$ & 12 & 40,0 & 7 & $\begin{array}{l}23,3 \\
3\end{array}$ & 0 & $\begin{array}{c}0,0 \\
0\end{array}$ & 0 & $\begin{array}{c}0,0 \\
0\end{array}$ & $\begin{array}{l}3 \\
0\end{array}$ & 100 & 82,66 \\
\hline $\begin{array}{ll}\text { Puas } & \text { Terhadap } \\
\text { Fasilitas } & \end{array}$ & & & & & & & & & & & & & 85,99 \\
\hline $\begin{array}{llr}5 . & \text { Fasilitas } & \text { yang } \\
& \text { diberikan } & \text { sudah } \\
\text { memadai } & \end{array}$ & $\begin{array}{l}1 \\
0\end{array}$ & $\begin{array}{c}33,3 \\
3\end{array}$ & 15 & 50,0 & 5 & $\begin{array}{c}16,6 \\
6\end{array}$ & 0 & $\begin{array}{l}0,0 \\
0\end{array}$ & 0 & $\begin{array}{l}0,0 \\
0\end{array}$ & $\begin{array}{l}3 \\
0\end{array}$ & 100 & 83,33 \\
\hline $\begin{array}{llr}6 . & \text { Fasilitas } & \text { yang } \\
& \text { diberikan } & \text { sudah } \\
\text { sesuai } & \text { dengan } \\
& \text { kinerja karyawan }\end{array}$ & $\begin{array}{l}1 \\
1\end{array}$ & $\begin{array}{c}36,6 \\
6\end{array}$ & 11 & $\begin{array}{c}36,6 \\
6\end{array}$ & 7 & $\begin{array}{c}23,3 \\
3\end{array}$ & 1 & $\begin{array}{l}3,3 \\
3\end{array}$ & 0 & $\begin{array}{l}0,0 \\
0\end{array}$ & $\begin{array}{l}3 \\
0\end{array}$ & 100 & 88,66 \\
\hline & & & & & & & & & & & & & 83,16 \\
\hline
\end{tabular}

\section{Motivasi}

Capaian nilai untuk variabel Motivasi adalah sebesar $76,83 \%$, dengan perincian indikator usaha karyawan karyawan memiliki motivasi yang tinggi untuk bekerja responden yang menjawab sangat setuju sebanyak 12 orang $(40,0 \%)$, responden yang menjawab setuju sebanyak 4 orang $(13,33 \%)$, responden yang menjawab kurang setuju sebanyak 13 orang $(43,33 \%)$, responden yang menjawab tidak setuju sebanyak 1 orang (3,33\%), responden yang menjawab sangat tidak setuju tidak ada $(0,00 \%)$

Selanjutnya pada indikator kebutuhan rasa aman dan keselamatan capaian indikator sebesar $79,66 \%$ dimana pada item pertanyaan pertanyaan Kinerja yang diberikan selama ini dihargai oleh perusahaaan responden yang menjawab sangat setuju sebanyak 14 orang $(46,66 \%)$, responden yang menjawab setuju sebanyak 5 orang $(16,66 \%)$, responden yang menjawab kurang setuju sebanyak 10 orang $(33,33 \%)$, responden yang menjawab tidak setuju sebanyak 1 orang $(3,33 \%)$ dan sangat tidak setuju tidak ada $(0,00 \%)$.

Selanjutnya pada indikator Karyawan merasa aman dan nyaman dalam bekerja responden yang menjawab sangat setuju sebanyak 11 orang $(36,66 \%)$, responden yang menjawab setuju sebanyak 6 orang $(20,0 \%)$, responden yang menjawab kurang setuju sebanyak 12 orang $(40,0 \%)$, responden yang menjawab tidak setuju sebanyak 1 orang $(3,33 \%)$, responden yang menjawab sangat tidak setuju tidak ada $(0,00 \%)$

Pada variabel motivasi item pertanyaan Kinerja yang diberikan selama ini dihargai oleh perusahaaan mendapatkan nilai tertinggi sebesar 4,06, hal ini menandakan bahwa karyawan pada Hotel Aston Kupang \& Covention Center bertanggung jawab sehingga dapat menyelesaikan tugas berdasarkan 
kesadaran. Sedangkan item pertanyaan motivasi Karyawan memiliki motivasi yang tinggi untuk bekerja dan Karyawan merasa aman dan nyaman dalam bekerja mendapatkan nilai terendah sebesar 3,09. Hal ini menandakan bahwa manajement Hotel Aston Kupang \& Covention Center harus meningkatkan hubungan relasi yang baik di lingkungan kerja non fisik dengan para karyawan lainnya.

\section{Capaian Indikator Variabel Motivasi}

\begin{tabular}{|c|c|c|c|c|c|c|c|c|c|c|c|c|c|}
\hline \multirow{3}{*}{ Indikator } & \multicolumn{9}{|c|}{ Jawaban Pertanyaan } & \multicolumn{2}{|c|}{ Total } & \multirow{2}{*}{\multicolumn{2}{|c|}{$\begin{array}{l}\text { Capaian } \\
\text { Indikator }\end{array}$}} \\
\hline & \multicolumn{2}{|r|}{5} & \multicolumn{2}{|r|}{4} & \multicolumn{2}{|r|}{3} & \multicolumn{2}{|r|}{2} & 1 & & & & \\
\hline & $\mathbf{F}$ & $\%$ & $\mathbf{F}$ & $\%$ & $F$ & $\%$ & $\mathbf{F}$ & $\%$ & $\mathbf{F}$ & $\%$ & $\mathbf{F}$ & $\%$ & $\%$ \\
\hline Usaha Karyawan & & & & & & & & & & & & & 74,00 \\
\hline $\begin{array}{l}\text { 1. Karyawan memiliki } \\
\text { motivasi yang tinggi } \\
\text { untuk bekerja }\end{array}$ & $\begin{array}{l}1 \\
2\end{array}$ & 40,0 & 4 & $\begin{array}{c}13,3 \\
3\end{array}$ & $\begin{array}{l}1 \\
3\end{array}$ & $\begin{array}{c}43,3 \\
3\end{array}$ & 1 & $\begin{array}{c}3,3 \\
3\end{array}$ & 0 & $\begin{array}{c}0,0 \\
0\end{array}$ & $\begin{array}{l}3 \\
0\end{array}$ & 100 & 74,00 \\
\hline $\begin{array}{lr}\text { Kebutuhan } & \text { Rasa } \\
\text { Aman } & \text { dan } \\
\text { Keselamatan } & \end{array}$ & & & & & & & & & & & & & 79,66 \\
\hline $\begin{array}{llr}\text { 2. } & \text { Kinerja } & \text { yang } \\
\text { diberikan selama ini } \\
\text { di } & \text { hargai } \\
\text { perusahaan } & \end{array}$ & $\begin{array}{l}1 \\
4\end{array}$ & $\begin{array}{c}46,6 \\
6\end{array}$ & 5 & $\begin{array}{l}16,6 \\
6\end{array}$ & $\begin{array}{l}1 \\
0\end{array}$ & $\begin{array}{c}33,3 \\
3\end{array}$ & 1 & $\begin{array}{c}3,3 \\
3\end{array}$ & 0 & $\begin{array}{c}0,0 \\
0\end{array}$ & $\begin{array}{l}3 \\
0\end{array}$ & 100 & 81,33 \\
\hline $\begin{array}{l}\text { 3. Karyawan merasa } \\
\text { nyaman dan aman } \\
\text { dalam bekerja }\end{array}$ & $\begin{array}{l}1 \\
1\end{array}$ & $\begin{array}{c}36,6 \\
6\end{array}$ & 6 & 20,0 & $\begin{array}{l}1 \\
2\end{array}$ & 40,0 & 1 & $\begin{array}{c}3,3 \\
3\end{array}$ & 0 & $\begin{array}{c}0,0 \\
0\end{array}$ & $\begin{array}{l}3 \\
0\end{array}$ & 100 & 78,00 \\
\hline & & & & ar & & & & & & & & & 76,83 \\
\hline
\end{tabular}

\section{Kinerja}

Capaian nilai untuk variabel Kualitas adalah sebesar $85,82 \%$, Pada item pertanyaan Karyawan selalu menyelesaikan pekerjaan dengan baik sesuai dengan prosedur yang berlaku responden yang menjawab sangat setuju sebanyak 19 orang $(63,33 \%)$, responden yang menjawab setuju sebanyak 5 orang $(16,66 \%)$, responden yang menjawab kurang setuju sebanyak 5 orang $(16,66 \%)$, responden yang menjawab tidak setuju sebanyak 1 orang $(3,33)$ dan sangat tidak setuju tidak ada $(0,00 \%)$.

Selanjutnya pada indikator Karyawan dapat menyelesaikan pekerjaan sesuai dengan arahan yang berlaku responden yang menjawab sangat setuju sebanyak 19 orang $(63,33 \%)$, responden yang menjawab setuju sebanyak 6 orang $(20,0 \%)$, responden yang menjawab kurang setuju sebanyak 5 orang $(16,66 \%)$, responden yang menjawab tidak setuju dan sangat tidak setuju tidak ada $(0,00 \%)$.

Capaian indikator kuantitas dengan nilai 85,99 pada indikator pertanyaan Karyawan dapat menyelesaikan pekerjaan sesuai tingkat waktu yang diberikan responden yang menjawab sangat setuju sebanyak 15 orang $(50,0 \%)$, responden yang menjawab setuju sebanyak 13 orang $(43,33 \%)$, responden yang menjawab kurang setuju sebanyak 2 orang $(6,66 \%)$, responden yang menjawab tidak setuju dan sangat tidak setuju tidak ada $(0,00 \%)$

Pada indikator Karyawan dapat menyelesaikan pekerjaan sesuai tingkat waktu yang diberikan oleh pimpinan responden yang menjawab sangat setuju sebanyak 14 orang $(46,66 \%)$, responden yang menjawab setuju sebanyak 8 orang $(26,66 \%)$, responden yang menjawab kurang setuju sebanyak 7 orang $(23,33 \%)$, reponden yang menjawab tidak 
setuju 1 orang $(3,33 \%)$ dan sangat tidak setuju tidak ada $(0,00 \%)$.

Pada variabel Kualitas Kinerja item pertanyaan dalam Karyawan dapat menyelesaikan pekerjaan sesuai dengan arahan yang berlaku mendapatkan nilai tertinggi sebesar $89,33 \%$, hal ini menandakan bahwa karyawan pada Hotel Aston Kupang \& Covention Center bertanggung jawab dalam tugas dan pekerjaan dengan tingkat kesadaran yang tinggi sesuai dengan harapan perusahaan. Sedangkan item pertanyaan Karyawan selalu menyelesaikan pekerjaan dengan baik sesuai dengan prosedur yang berlaku mendapatkan nilai terendah sebesar $83,33 \%$ Hal ini menandakan bahwa manajement Hotel Aston Kupang \& Covention Center harus meningkatkan kesadaran bagi setiap karyawan hotel agar mampu memberikan kualitas pelayanan yang memuaskan bagi para pengunjung hotel yang menginap.

\begin{tabular}{|c|c|c|c|c|c|c|c|c|c|c|c|c|c|}
\hline \multicolumn{14}{|c|}{ Capaian Indikator Variabel Kinerja } \\
\hline \multirow{3}{*}{ Indikator } & \multicolumn{10}{|c|}{ Jawaban Pertanyaan } & \multicolumn{2}{|c|}{ Total } & \multirow{3}{*}{$\begin{array}{c}\text { Capaian } \\
\text { Indikator } \\
\%\end{array}$} \\
\hline & \multicolumn{2}{|r|}{5} & \multicolumn{2}{|r|}{4} & \multicolumn{2}{|r|}{3} & \multicolumn{2}{|c|}{2} & \multicolumn{2}{|c|}{1} & & & \\
\hline & $\mathbf{F}$ & $\%$ & $\mathbf{F}$ & $\%$ & $\mathbf{F}$ & $\%$ & $\mathbf{F}$ & $\%$ & $\mathbf{F}$ & $\%$ & $\mathbf{F}$ & $\%$ & \\
\hline Kualitas & & & & & & & & & & & & & 85,66 \\
\hline $\begin{array}{l}\text { 1. Karyawan selalu } \\
\text { menyelesaikan } \\
\text { pekerjaan } \\
\text { dengan baik } \\
\text { sesuai dengan } \\
\text { prosedur yang } \\
\text { berlaku }\end{array}$ & 19 & \begin{tabular}{|l|}
63,3 \\
3
\end{tabular} & 5 & $\begin{array}{c}16,6 \\
6\end{array}$ & 5 & $\begin{array}{c}16,6 \\
6\end{array}$ & 1 & $\begin{array}{c}3,3 \\
3\end{array}$ & 0 & $\begin{array}{c}0,0 \\
0\end{array}$ & 30 & 100 & 88,00 \\
\hline $\begin{array}{l}\text { 2. Karyawan dapat } \\
\text { menyelesaikan } \\
\text { pekerjaan sesuai } \\
\text { dengan arahan } \\
\text { yang berlaku }\end{array}$ & 19 & $\begin{array}{c}63,3 \\
3\end{array}$ & 6 & 20,0 & 5 & 16,7 & 0 & $\begin{array}{l}0,0 \\
0\end{array}$ & 0 & $\begin{array}{c}0,0 \\
0\end{array}$ & 30 & 100 & 89,33 \\
\hline Kuantitas & & & & & & & & & & & & & 85,99 \\
\hline $\begin{array}{l}\text { 3. Karyawan dapat } \\
\text { menyelesaikan } \\
\text { pekerjaan sesuai } \\
\text { tingkat waktu } \\
\text { yang diberikan }\end{array}$ & $\begin{array}{l}1 \\
5\end{array}$ & 50,0 & $\begin{array}{l}1 \\
3\end{array}$ & $\begin{array}{l}43,3 \\
3\end{array}$ & 2 & 6,66 & 0 & $\begin{array}{c}0,0 \\
0\end{array}$ & 0 & $\begin{array}{c}0,0 \\
0\end{array}$ & 30 & 100 & 88,66 \\
\hline $\begin{array}{l}\text { 4. Karyawan dapat } \\
\text { menyelesaikan } \\
\text { pekerjaan sesuai } \\
\text { tingkat waktu } \\
\text { yang diberikan } \\
\text { oleh pimpinan } \\
\end{array}$ & 14 & $\begin{array}{c}46,6 \\
6\end{array}$ & 8 & $\begin{array}{l}26,6 \\
6\end{array}$ & 7 & $\begin{array}{l}23,3 \\
3\end{array}$ & 1 & $\begin{array}{l}3,3 \\
3\end{array}$ & 0 & $\begin{array}{c}0,0 \\
0\end{array}$ & 30 & 100 & 83,33 \\
\hline & & & & $\mathrm{nV}$ & & & & & & & & & 85,82 \\
\hline
\end{tabular}

\section{Uji Instrumen}

\section{Uji validitas}

Tabel 6

\begin{tabular}{|l|l|l|l|l|}
\hline Variabel & Item Peryataan & $\mathrm{R}$ hitung & $\mathrm{R}$ tabel & Keterangan \\
\hline
\end{tabular}


Dra. Rulli Saragi, M.Hum

\begin{tabular}{|c|c|c|c|c|}
\hline \multirow[b]{2}{*}{ Kompensasi } & $\mathrm{X} 1$ & 0,715 & 0,361 & Valid \\
\hline & $\mathrm{X} 2$ & 0,927 & 0,361 & Valid \\
\hline \multirow{4}{*}{ (X1) } & $\mathrm{X3}$ & 0,786 & 0,361 & Valid \\
\hline & $\mathrm{X} 4$ & 0,813 & 0,361 & Valid \\
\hline & $\mathrm{X5}$ & 0,854 & 0,361 & Valid \\
\hline & $\mathrm{X} 6$ & 0,891 & 0,361 & Valid \\
\hline \multirow{3}{*}{$\begin{array}{c}\text { Motivasi } \\
\text { (X2) }\end{array}$} & $\mathrm{X} 1$ & 0,761 & 0,361 & Valid \\
\hline & $\mathrm{X} 2$ & 0,792 & 0,361 & Valid \\
\hline & $\mathrm{X3}$ & 0,888 & 0,361 & Valid \\
\hline \multirow{4}{*}{$\begin{array}{c}\text { Kinerja } \\
(\mathrm{Y})\end{array}$} & $\mathrm{Y1}$ & 0,663 & 0,361 & Valid \\
\hline & $\mathrm{Y} 2$ & 0,831 & 0,361 & Valid \\
\hline & $\mathrm{Y3}$ & 0,785 & 0,361 & Valid \\
\hline & Y4 & 0,803 & 0,361 & Valid \\
\hline
\end{tabular}

\section{Uji Reliabilitas}

Tabel 7

Uji Reliabilitas

\begin{tabular}{|l|c|c|l|}
\hline \multicolumn{1}{|c|}{ Variabel } & $\begin{array}{c}\text { Nilai Cronbach's } \\
\text { Alpha }\end{array}$ & $\begin{array}{c}\text { Nilai Kriteria Nilai } \\
\text { Cronbach's Alpha }\end{array}$ & Ket \\
\hline Kompensasi & 0,913 & 0,60 & Realibel \\
\hline Motivasi & 0,746 & 0,60 & Realibel \\
\hline Kinerja & 0,773 & 0,60 & Realibel \\
\hline
\end{tabular}

Sumber: Data primer, diolah lebih lanjut (2012)

Dari hasil perhitungan SPSS16 maka diperoleh nilai cronbach's alpha lebih besar dari 0,60 dan dengan demikian dapat ditarik kesimpulan bahwa indikator dalam bentuk pernyataan variabel kompensasi,variabel motivasi dan kinerja karyawan yang dapat dipercaya sebagai alat ukur.

Analisis Pengaruh Kompensasi, Motivasi, dan Kinerja terhadap Analisis Regresi.
Untuk mengetahui pengaruh Kompensasi, Motivasi, Kinerja terhadap karyawan pada Hotel Asto Kupang \& covention center, digunakan analisis kuantitatif dengan model regresi linear. Hasil olahan dapat dapat diperoleh sebagaimana tercatat pada tabel berikut ini.

Tabel 8

Hasil Regresi Linear Berganda 
Dra. Rulli Saragi, M.Hum

\begin{tabular}{|c|c|c|c|c|}
\hline Variabel & $\begin{array}{c}\text { Koefisien } \\
\text { Regresi }\end{array}$ & Beta & t Hitung & Tingkat Signifikan \\
\hline Konstanta & 23,340 & & 8,275 & 0,000 \\
\hline Kompensasi (X1) & 0,026 & 0,057 & 0,261 & 0,796 \\
\hline Motivasi (X2) & 0,402 & 0,334 & 1,522 & 0,140 \\
\hline F Hitung & \multicolumn{4}{|c|}{2,141} \\
\hline Sig & \multicolumn{4}{|c|}{0,137} \\
\hline $\mathrm{R}$ & \multicolumn{4}{|c|}{0,370} \\
\hline R Square & \multicolumn{4}{|c|}{0,137} \\
\hline Adjusted $\mathrm{R}^{2}$ & \multicolumn{4}{|c|}{0,073} \\
\hline
\end{tabular}

Dari tabel diatas diketahui Kompensasi, Motivasi , dan Kinerja berpengaruh terhadap Kinerja Karyawan yang ditandai dengan koefisien regresi nilai kompensasi sebesar 0,26 koefisien regresi nilai Motivasi sebesar 0,402 dan koefisien regresi nilai kinerja karyawan sebesar 23,340.

Berdasarkan tabel tersebut, maka model persamaan regresi linear berganda adalah sebagai berikut: $Y=23,340+0,226 \mathrm{X} 1+$ $0,402 \times 2$ Sesuai dengan persamaan garis regresi yang diperoleh, maka model regresi tersebut dapat diinterpretasikan sebagai berikut:

1. Harga koefisien konstanta $=23.340$, hal ini menunjukkan apabila nilai $\mathrm{X} 1$ (Kompensasi), $\mathrm{X} 2$ (Motivasi), dan $\mathrm{Y}$ (Kinerja Karyawan) pada Hotel Aston Kupang \& Covention Center sama dengan nol, maka tingkat atau besarnya Kinerja karyawan pada Hotel Aston Kupang \& Covention Center akan sebesar 23,340

2. Harga koefisien $b 1=0,26$, berarti bahwa apabila nilai $\mathrm{X} 1$ mengalami kenaikan sebesar 1 (satu) poin, sementara variabel nilai X2 tetap, maka tingkat atau besarnya kinerja karyawan akan meningkat pada Hotel On The Rock akan sebesar 0,26

3. Harga koefisien b2 $=0,402$, berarti bahwa bila kenaikan nilai sebesar 1 (satu) poin pada $\mathrm{X} 2$, sementara variabel $\mathrm{X} 1$ tetap, maka maka tingkat atau besarnya kinerja karyawan akan meningkat pada Hotel Aston Kupang \& Covention Center akan sebesar $=0,402$

\section{PEMBAHASAN}

Jumlah 30 responden yang mengunjungi Hotel Aston Kupang \& Covention Center yang dihitung berdasarkan Jenis Klamin, Usia, dan tingkat pendidikan terakhir adalah laki-laki sebanyak 21 orang $(70,0 \%)$ dan perempuan 9 orang (30,0\%), Usia 21-30 Tahun sebanyak $21(70 \%)$ Orang dan responden dengan 31-43 Tahun sebanyak 9(30\%)Orang, Pendidikan terakir responden dengan pendidikan SLTA sebanyak 10 Orang (33,3\%) kemudian responden dengan pendidikan D3 sebanyak 7 Orang $(23,3 \%)$, selanjutnya S1 sebanyak 3 Orang $(10,00 \%)$ dan tingkat pendidikan lainnya sebanyak 10 Orang(33,3\%)

Hasil penelitian tentang kompensasi dengan indikator puas terhadap gaji dan puas terhadap fasilitas memperoleh presentase yang tinggi atau baik yaitu sebesar $83,16 \%$. Hal ini berarti karyawan telah meningkatkan prestasi kerja dalam memuaskan pelanggan yang datang berkunjung sehingga karyawan mendapatkan bonus yang diberikan oleh pihak hotel.

Pada indikator gaji yang diberikan karyawan sudah memadai memperoleh presentase baik $75,33 \%$.

Pada indikator gaji yang diberikan sudah sesuai dengan kinerja karyawan memperoleh presentase baik $80,0 \%$

Pada indikator gaji yang diberikan sudah dapat memenuhi kebutuhan karyawan memperoleh presentase baik $83,33 \%$

Pada indikator gaji yang diberikan sudah sesuai dengan peratutan yang berlaku memperoleh prestanse baik $82,66 \%$

Berdasarkan Hasil penelitian tentang Motivasi dengan indikator usaha karyawan dan 
kebutuhan dan rasa aman dan keselamatan memperoleh presentase baik 79,66\%. Pada indikator karyawan memiliki motivasi yang tinggi untuk bekerja memperoleh presentase baik $74,00 \%$. Pada indikator pertanyaan kinerja yang diberikan selama ini di hargai oleh perusahaan memperoleh presentase baik 81,33\%.Pada indikator pertanyaan karyawan merasa nyaman dan aman dalam bekerja memeperoleh presentase baik 78,00\%

Motivasi yang dimaksudkan merupakan sesuatu yang diterima karyawan sebagai pengganti kontribusi jasa mereka pada jasa perusahaan.

hasil peneliyian dengan indikator kualitas dan kuantitas memperoleh presentase yang tinggi atau baik $85,82 \%$. Hal ini berarti karyawan merasa puas atas fasilitas yang diberikan oleh pihak hotel kepada kinerja karaywan.

Pada indikator karyawan selalu menyelesaikan pekerjaan dengan baik sesuai dengan prosedur yang berlaku memperoleh presentase sangat baik $88,00 \%$. Hal ini berarti karyawan menyeselaikan pekerjaan sesuai dengan harapan perusahaan

Pada indikator karyawan dapat menyelesaikan pekerjaan sesuai dengan arahan yang berlaku, memperoleh presentase sangat baik $89,33 \%$. Hal ini berarti karyawan bekerja sesuai dengan yang di harapkan oleh perusahaan dalam meningkatkan kualitas kinerja yang baik.

Pada indikator karyawan dapat menyelesaikan pekerjaan sesuai tingkat waktu yang diberikan memperoleh presentase sangat baik $88,66 \%$. Hal ini berarti karyawan mampu memberikan layanan yang baik dalam hal bekerja yang ramah, santun dan martabat. Pada indikator karyawan dapat menyelesaikan pekerjaan sesuai tingkat waktu yang diberikan oleh pimpinan memperoleh presentase baik $83,33 \%$. Hal ini berarti karyawan bekerja sesuai dengan efesiensi yang diterapkan dari pribadi masing-masing.

\section{PENUTUP}

\section{Kesimpulan}

Dari hasil penelitian dan pengujian yang telah dilakukan oleh penulis tentang pengaruh kompensasi dan motivasi tehadap kinerja karyawan pada Hotel Aston Kupang \& Covention Center penulis dapat mengambil kesimpulan sebagai berikut:

1. Terdapat pengaruh secara parsial antara Kompensasi terhadap kinerja karyawan yang ditandai dengan nilai t hitung sebesar 2,672
2. Terdapat pengaruh secara parsial anatara Motivasi terhadap kinerja karyawan yang ditandai dengan nilai $\mathrm{t}$ hitung sebesar 3,661

3. Terdapat pengaruh secara simultan antara variabel kompensasi, motivasi terhadap kinerja karyawan pada Hotel Hotel Aston Kupang \& Covention Center yang ditandai dengan nilai $\mathrm{F}$ hitung sebesar 9,224

4. Terdapat variabel lain yang berpengaruh terhadap kinerja karyawan Hotel Aston Kupang \& Covention Center yang selain kompensasi dan motivasi yang harus diperhatikan secara gaya kepemimpinan,budaya kerja dan variabel lainnya

\section{Saran}

1. Disarankan bagi Hotel Aston Kupang \& Covention Center kompensasi Gaji yang diberikan harus sesuai dengan kinerja karyawan. Agar karyawan yang bekerja sesuai dengan kompetensi dalam menerapkan kinerja karyawan hotel.

2. Disarankan Hotel Aston Kupang \& Covention Center perlu mempertahankan dan memperhatikan dan mengoptimalkan motivasi kinerja karyawan hotel dalam tugas dan tanggung jawab yang di bebankan.

3. Disarankan bagi Hotel Aston Kupang \& Covention Center antara variabel Kompensasi dan motivasi terus di tingkatkan secara bersama-sama dalam rangka meningkatkan kinerja karyawan Hotel Aston Kupang \& Covention Center

4. Disarankan bagi Hotel Aston Kupang \& Covention Center secara parsial maupun secara simultan mempertahankan gaya kepemimpinan, dan budaya yang di terapkan untuk kinerja karyawan hotel, agar mampu memberikan motivasi kerja yang baik.

\section{DAFTAR PUSTAKA}

Agiel Puji Damayanti, (2013). Pengaruh Kompensasi dan Motivasi Kerja Terhadap Kinerja Karyawan Perusahaan Daerah Air Minum (PDAM) Surakarta. Jurnal Penelitian. Pendidikan Ekonomi-BKK Akuntansi, FKIP Universitas Sebelas Maret

Candhis, Damar Iresha. (2013). Pengaruh Kompensasi dan Motivasi Kerja Terhadap Kinerja Karyawan Studi Komparatif Karyawan Bagian Akuntansi FE UNY. Skripsi. Fakultas Ekonomi. Universitas Negeri Yogyakarta. 
Ghozali, Imam. (2005). Aplikasi Analisis Multivariate dengan Program IBM SPSS19. Semarang : Badan Penerbit Universitas Diponegoro.

H. Moh Pabunda Tika, (2006). Budaya Organisasi dan Peningkatan Kinerja Prusahaan. Jakarta: Bumi Aksara.

Hasibuan, Malayu S.P. (2009). Manajemen Sumber Daya Manusia. Edisi Revisi 2009 . Jakarta : PT. Bumi Aksara .

Lekwikwati, Karel A. (2005). Analisis Pengaruh Kompensasi Finansial dan non finansial terhadap kepuasan kerja karyawan PDAM Kabupaten Yapen Waropen, Papua. Jurnal Aplikasi Manajemen.

Siagian, s.2007. Organisasi Kepemimpinan dan Perilaku Administrasi Cetakan Kelima. Massagung : Jakarta

Simamora. Henry.2004. Manajemen Sumber Daya Manusia. Cetakan Pertama. Yogyakarta:Bagian Penerbit STIE YKPN

Sugiono.(2016). Metode Penelitian Pendidikan. Pendekatan Kuantitatif, Kualitatif dan $R \& D$.Bandung : CV. Alfabeta

Tanto Wijaya dan Fransisca Andreani, (2005) Pengaruh Motivasi dan Kompensasi Terhadap Kinerja Karyawan Pada Pt sinar Jaya Abadi Bersama. Program Manajemen Bisnis, Program Study Manajemen, Universitas Kristen Petra JI. Siwalankerto 121-131, Surabaya. AGORA vol.3,2,(2015) 37

Wahjono, Imam Sentot .2008. Manajemen Tata Kelola Organisasi bisnis. Jakarta: Pt.Indeks. 